\title{
PENGARUH MOTIVASI DAN SEMANGAT KERJA TERHADAP \\ PENINGKATAN PRODUKTIVITAS KERJA KARYAWAN \\ PADA PT. COLOMBUS MEGAH SENTRASARANA DI SAMARINDA
}

\author{
Muchtar Hidayat \\ STIENAS Samarinda \\ Jalan W.R. Soepratman No. 10, Kelurahan Bugis, Samarinda Ulu Telp. (0541) 743607. \\ mukhtarrjabm@gmail.com
}

\section{ABSTRACT}

The purpose of this study is to determine the influence of motivation and morale towards the increase of work productivity of employees of PT. Colombus Megah Sentrasarana in Samarinda and to know the improvement of work productivity of employees with the provision of motivation.

Analysis uses multiple linear regression with SPSS tool. Correlation coefficient $(R)$ of 0.8770 means that the variables of motivation and morale together have a direct or positive relationship with employee productivity at PT. Colombus Megah Sentrasarana in Samarinda.

While the influence of each variable that is variable of motivation (X1) influences work productivity of employee equal to 63,80\%, while work spirit variable (X2) influence to work productivity equal to 71,50\%. So, it can be said that morale is the dominant variable of influence on employee productivity at PT. Colombus Megah Sentrasarana in Samarinda.

The first hypothesis test is acceptable because $F$ count is 69,808 and $F$ table 2,830 which means $F$ arithmetic $>F$ table. The second hypothesis can be accepted because it is proven that the morale of influence dominant effect on employee productivity at PT. Colombus Megah Sentrasarana in Samarinda.

\section{Keywords: Motivation, Spirit, and relationship with productivity}

\section{PENDAHULUAN}

Pertumbuhan dunia usaha dewasa ini semakin pesat, dimana masing-masing perusahaan berusaha semaksimal mungkin untuk mengelola sumber daya yang ada di perusahaan baik mesin, modal, material, pasar maupun sumber daya manusia. Sumber daya yang ada pada perusahaan harus benar-benar mendapat perhatian agar tujuan perusahaan dapat tercapai secara efektif dan efisien.

Sumber daya manusia merupakan salah satu faktor utama serta penentu keberhasilan suatu perusahaan, karena sumber daya manusia merupakan motor penggerak 
daik dari proses perencanaan, pengorganisasian, pengarahan sampai pada pengendalian sumbersumber yang ada pada perusahaan untuk pencapaian tujuan. Sumber daya manusia juga merupakan asset perusahaan yang perlu diperhatikan demi tercapainya kelangsungan hidup suatu perusahaan, yaitu bagaimana caranya meningkatkan produktivitas kerja.

Di dalam suatu organisasi atau badan usaha senantiasa terdapat dua pola kepentingan yaitu disatu pihak adalah peningkatan produktivitas kerja untuk pencapaiaan tujuan dari perusahaan dan dilain pihak untuk kepentingan kesejahteraan karyawan. Pimpinan perusahaan haruslah dan perlu memberikan rangsangan dan dorongan kepada karyawan, yaitu dengan memberikan motivasi.

Motivasi merupakan salah satu usaha untuk menggerakkan atau mengarahkan perilaku individu agar mau melakukan pekerjaan sesuai dengan tugas yang dibebankan kepadanya. Motivasi adalah motor penggerak dari individu karena setiap orang individu yang bekerja didorong oleh suatu kebutuhan tertentu dan dengan bekerja individu akan mendapatkan gaji, insetif ataupun bomus yang yang dapat digunakan untuk memenuhi kebutuhan tersebut.

$$
\text { PT. Colombus Megah }
$$

Sentrasarana salah satu perusahaan yang bergerak dalam bidang dagang. Banyaknya perusahaan lain yang bergerak dibidang yang sama, membuat persaingan yang semakin ketat antara perusahaan. Pelayanan yang memuaskan, fasilitas yang memadai, kemudahan-kemudahan yang diberikan kepada konsumen merupakan salah satu upaya yang harus dan selalu diperhatikan oleh perusahaan, dalam hal-hal tersebut bagian yang penting dalam pemasaran. Dilain pihak usaha untuk meningkatkan produktivitas kerja bukanlah suatu pekerjaan yang mudah bagi pihak manajemen, namun dalam rangka meningkatkan produktivitas kerja karyawan maka PT. Telkomsel mengambil kebijaksanaan dengan memberikan motivasi berupa pemberian insentif dan bonus. Pihak manajemen berharap dengan pemberian motivasi (insentif) dapat meningkatkan gairah kerja karyawan sehingga dapat pula 
meningkatkan produktivitas kerja karyawan.

Insentif dan bonus merupakan salah satu dari faktor motivasi yang dapat digunakan sebagai penggerak semangat kerja karyawan yang pada akhirnya akan memberikan kontribusi bagi peningkatan produktivitas kerja karyawan. Namun sampai saat ini perusahaan belum mengetahui apakah kebijaksanaan pemberian motivasi tersebut memberikan kontribusi terhadap peningkatan produktivitas kerja karyawan pada PT. Colombus Megah Sentrasarana di Samarinda.

Mengacu pada uraian tersebut di atas, penulis tertarik memberi judul penelitian ini "Pengaruh Motivasi dan Semangat Kerja Terhadap Produktivitas Kerja Karyawan Pada PT. Colombus Megah Sentrasarana di Jalan Dr. Soetomo Samarinda".

\section{KERANGKA TEORITIS}

Manajemen Sumber Daya Manusia

\footnotetext{
Manajemen sebagai seni berfungsi mencapai tujuan yang nyata mendatangkan hasil dan manfaat, sedangkan manajemen ilmu
}

berfungsi menerangkan gejala-gejala, kejadian-kejadian suatu keadaan.

Menurut H. Malayu Hasibuan, (2005:1) "Manajemen adalah ilmu dan seni mengatur proses pemanfaatan sumber daya manusia dan sumber-sumber lainnya secara efektif dan efesien".

Manajemen merupakan suatu ilmu dan seni, berarti seseorang yang belajar manajemen belum tentu akan menjadi seorang manajer yang baik. tergantung pada kemampuan manajer membuat perencanaan, mengorganisasikan, menyusun, menggerakan dan mengawasi sumber daya, terutama sumber daya manusia yang merupakan faktor produksi yang paling sulit digerakan. Manajemen memegang peranan yang sangat penting karena manajemen mempersoalkan usaha penetapan serta pencapaian tujuan yang diinginkan.

T. Hani Handoko (2006:4), Manajemen Sumber Daya Manusia adalah penarikan, seleksi pengembangan, pemeliharaan dan penggunaaan sumber daya manusia untuk mencapai baik tujuan-tujuan individu maupun organisasi. 
Manajemen personalia adalah sebagai cabang ilmu manajemen atau yang sekarang lebih dikenal dengan sebutan manajemen sumber daya manusia. Dimana manajemen sumber daya manusia menitik beratkan perhatian pada faktor tenaga kerja. Dari batasan tersebut, manajemen sumber daya manusia menekankan bagaimana memperoleh karyawan, memberikan fasilitas untuk pengembangan pegawai dan keikutsertaan pegawai dalam suatu organisasi, dengan demikian produktivitas dapat ditingkatkan, dengan kata lain manajemen sumber daya manusia dalam organisasi tujuannya adalah memberikan kepada organisasi satuan kerja yang efektif.

Menurut Soekidjo Notoatmodjo (2007:109), Manajemen sumber daya manusia (personalia) adalah perencanaan, pengorganisasian, pengarahan dan pengawasan kegiatan-kegiatan, pengadaan, pengembangan, pemberian kompensasi, pengintegrasian, pemeliharaan dan pelepasan sumber daya manusia agar tercapai berbagai tujuan individu, organisasi dan masyarakat.
Manajemen sumber daya manusia adalah pengembangan dan pemanfaatan personil (pegawai) bagi pencapaian yang efektif mengenai sasaran-sasaran dan tujuan-tujuan individu, organisasi, masyarakat, nasional dan internasional. Manajemen sumber daya manusia terus berkembang sejalan dengan kemajuan dan tantangan jaman. Suatu perkembangan yang patut diperhatikan dalam manajemen sumber daya manusia adalah ditemukannya kecenderungankecenderungan baru yang berdampak positif terhadap perkembangan dan efektivitas organisasi.

\section{Motivasi}

"Motivasi merupakan kegiatan yang mengakibatkan, menyalurkan dan memelihara perilaku manusia, agar mau melakukan pekerjaan yang diberikan kepadanya" (Handoko, 2006: 251)

Menurut Malayu S.P. Hasibuan (2005: mendefinisikan "Motivasi adalah hal yang menyebabkan, menyalurkan dan mendukung perilaku manusia supaya mau bekerja giat dan antusias untuk mencapai hasil yang optimal". 
Hal ini senada yang diungkapkan oleh John Campbell et.al yang dikutip oleh Abi Sujak (2000: 72), Motiv mencakup didalamnya arah dan tujuan tingkah laku, kekuatan respon dan kegigihan tingkah laku. Disamping itu, istilah itu mencakup sejumlah konsep seperti dorongan (drive), kebutuhan (needs), rangsangan (incentive), ganjaran (reward), penguatan (reinforcement), ketepatan tujuan (goal setting), harapan (expentancy), dan sebagainya.

Hal ini senada yang diungkapkan oleh John P. Campbell, et.al dikutip Henry Simamora (2004: 72), Motivasi mencakup di dalamnya arah dan tujuan tingkah laku, kekuatan respon dan kegigihan tingkah laku. Disamping itu, istilah itu mencakup sejumlah konsep seperti dorongan (drive), kebutuhan (needs), rangsangan (incentive), ganjaran (reward), penguatan (reinforcement), ketepatan tujuan (goal setting), harapan (expentancy), dan sebagainya.

Secara mendasar Komaruddin (2004:266), mengartikan motivasi adalah, Penyebab tindakan; kondisi yang memulai tingkah laku atau kegiatan pada dasarnya motivasi itu dapat dibagi menjadi dua jenis utama. (1) Motivasi intrinsik adalah motivasi yang timbul dari dalam diri seseorang, misalnya kenaikan pangkat, pujian, hadiah dan sebagainya. Motivasi terdiri dari dua unsur yaitu unsur luar dan unsur dalam. Unsur dalam adalah perubahan yang terjadi pada diri seseorang, misalnya ketegangan jiwa dan rasa tidak puas. Unsur luar adalah sesuatu yang ingin dicapai seseorang (tujuan). Motivasi bermanfaat kepada manajemen karena motivasi itu berfungsi sebagai penggerak, pengarah, dan pendorong terjadinya perbuatan.

Motivasi dapat ditafsirkan dan diartikan berbeda oleh tiap orang, sesuai dengan tempat dan keadaan dari masing-masing orang tersebut. Salah satu diantara pengguna istilah dan konsep motivasi ini adalah untuk menggambarkan hubungan antara harapan dan tujuan. Dan tiap orang dan organisasi selalu ingin dapat mencapai beberapa tujuan dari kegiatan-kegiatannya. Karena keanggotaan seseorang dalam suatu organisasi berpengaruh terhadap tujuan dan tingkah lakunya dalam 
mencapai tujuannya itu ditambah lagi dengan beraneka ragamnya hubungan yang alami seseorang dalam organisasi, maka hal tersebut banyak menentukan motivasi dan tingkah laku pencarian atas pencapaian tujuan.

\section{Semangat Kerja}

Bagi setiap manusia tentu akan merasakan dan memahami bahwa semangat merupakan sesuatu yang memberikan dorongan untuk melakukan kegiatan dengan penuh gairah, dalam arti dilakukan dengan senang hati, jadi pegawai tersebut sangat jauh dari sifat keterpaksaan, sehingga betapapun beratnya pegawai tersebut tidak akan terasa dan diterima dengan baik.

Pengertian semangat kerja dari segi etimologi bahasa dikatakan $\begin{array}{lll}\text { Sondang } & \text { P. } & \text { Siagian }\end{array}$ (2005:155), "Semangat kerja adalah nafsu (kemauan) untuk bekerja, dan kerja adalah perbuatan melakukan sesuatu."

Moekijat (2002: 172), Semangat kerja sama yang tinggi berarti bahwa karyawan merasa gembira dalam bekerja, tidak memberikan kritik terhadap karyawan dan hubungan kerja. Sebaliknya kalau semangat kerjasama rendah, banyak pegawai merasa tidak puas dan banyak kritik yang dilontarkan kepada pimpinan maupun kepada pemberi kerja.

Dari pendapat di atas di peroleh petunjuk bahwa dengan adanya iklim semangat kerja karyawan yang baik, mempunyai kaitan yang erat dengan tujuan organisasi kerja, terutama usaha untuk meningkatkan hasil kerja sesuai dengan ketentuan-ketentuan yang telah ditetapkan sebelumnya. Dengan kata lain dapat dikatakan bahwa dengan semangat kerja pegawai yang baik dapat mewujudkan sesuatu kegiatan yang baik, tanggung jawab dan disiplin yang tinggi dan adanya keberanian yang positif.

\section{Produktivitas Kerja}

Secara umum produktivitas diartikan sebagai hubungan antara hasil nyata maupun fisik (barang atau jasa) dengan masukan yang sebenarnya. Dengan kata lain produktivitas adalah perbandingan antara input dan output. Juga bisa diartikan tingkatan efesiensi dalam memproduksi barang atau jasa.

Produktivitas menurut Dewan Produkivitas Nasional (Depnaker RI) dirumuskan yaitu, Produktivitas adalah sikap mental yang selalu 
mempunyai pandangan bahwa mutu kehidupan hari ini harus lebih baik dari hari kemarin dan hari esok harus lebih baik dari hari ini. (Manullang dan Andreas, 2003 : 11)

Batasan

mengenai

produktivitas dapat dilihat dari berbagai sudut pandang tergantung pada tujuan masing-masing organisasi (misalnya untuk profit ataukah untuk costumer satisfaction), juga tergantung pada bentuk organisasi itu sendiri.

Pengertian lain dari produktivitas yaitu menurut Rusli Syarif (2001:1) adalah sebagai berikut: "Produktivitas kerja adalah hubungan kualitas yang dihasilkan dengan jumlah kerja yang dilakukan untuk mencapai hasil tersebut".

Jadi yang mendorong seseorang untuk bekerja sebaikbaiknya dalam suatu organisasi atau perusahaan adalah tergantung sejauhmana perselisihan tujuan perseorangan dalam suatu badan usaha. Semakin diperhatikan keinginan karyawan, semakin giatlah karyawan bekerja. Jelaslah bahwa produktivitas kerja dapat dicapai dengan memperhatikan tujuan-tujuan perseorangan dalam suatu organisasi, alatnya adalah dengan memberikan insentif kepada karyawan. Namun pemberian insentif tidak berarti produktivitas karyawan dapat ditingkatkan. Karena selain insentif ada faktor-faktor lain yang mempengaruhi produktivitas kerja karyawan seperti: pendidikan, gizi, kesempatan kerja, bakat atau bawaan dan lain-lain.

\section{Hipotesis Penelitian}

Atas dasar kerangka teoritis di atas, maka hipotesis yang diajukan dalam penelitian ini adalah: Di duga motivasi dan semangat kerja secara simultan berpengaruh terhadap produktivitas kerja karyawan pada PT. Colombus Megah Sentrasarana di Samarinda, dan diduga semangat kerja berpengaruh lebih besar terhadap produktivitas kerja karyawan pada PT. Colombus Megah Sentrasarana di Samarinda.

\section{METODE PENELITIAN \\ Definisi Operasional}

Untuk memberikan arah bagi penelitian yang akan dilakukan dirasa perlu untuk mengoperasionalkan variabel yang diteliti, agar variabel tersebut dapat diukur.

Yang dimaksud dengan
motivasi adalah kegiatan untuk 
mengarahkan prilaku individu agar melaksanakan tugasnya dengan baik. Motivasi disini dapat berupa pemberian insentif dari perusahaan secara langsung kepada karyawan selain gaji pokoknya serta pemberian bonus dengan tujuan agar dapat melakukan tugasnya dengan lebih baik dan giat. Dalam penulisan ini motivasi merupakan variabel bebas yang diberi simbol (X1).

Semangat kerja dalam penulisan ini adalah sikap dari karyawan pada PT. Colombus Megah Sentrasarana dalam menyelesaikan pekerjan yang ditugaskan kepadanya yang berkaitan dengan kegairahan dalam bekerja, disiplin kerja dan tingkat kerjasama antara sesama karyawan dalam usaha mencapai tujuan yang ditentukan dari instansi sebelumnya. Semangat kerja adalah variabel bebas yang diberi simbol (X2), indikator semagat kerja karyawan meliputi:

1. Tingkat Disiplin Kerja

2. Tingkat Gairah Kerja

3. Tingkat Kerjasama Karyawan

4. Tingkat Kemampuan Karyawan Yang dimaksud dengan produktivitas tenaga kerja dalam penulisan ini adalah kemampuan tenaga kerja dengan jalan membandingkan hasil produksi (output) dengan jumlah tenaga kerja (input). Dalam penulisan ini disebut sebagai variabel terikat, dengan menggunakan simbol (Y).

\section{Alat Analisis dan Pengujian Hipotesis}

Untuk mengetahui seberapa besar motivasi dan semangat kerja yang mempengaruhi produktivitas pada PT. Colombus Megah Sentrasarana di Jalan Dr. Soetomo Samarinda, maka yang menjadi variabel dependen adalah produktivitas (Y) sedangkan variabel independent adalah yang meliputi (X1) motivasi dan semangat kerja (X2).

1. Alat Analisis

Adapun alat analisis yang digunakan dalam penelitian ini adalah analisa regresi linier berganda dengan persamaan sebagai berikut:

$$
\mathrm{Y}=\mathrm{a}+\mathrm{b}_{1} \quad \mathrm{X}_{1}+\mathrm{b}_{2} \mathrm{X}_{2}+\mathrm{e}(\mathrm{J} .
$$

Supranto, $2004: 208$ )

Keterangan :

$\mathrm{Y}=$ Produktivitas Kerja Karyawan

$\mathrm{a}=$ Konstanta

$\mathrm{X}_{1}=$ Motivasi

$\mathrm{X}_{2}=$ Semangat Kerja

$\mathrm{b}_{1}, \mathrm{~b}_{2}=$ Koefisien Regresi

$\mathrm{e}=$ Kesalahan Pengganggu

2. Pengujian hipotesis

Untuk menguji hipotesis maka penulis menggunakan uji F (uji 
serentak) dan uji t (Uji parsial), uji $\mathrm{R}^{2}$ dan $\mathrm{r}^{2}$ untuk mengetahui pengaruh antara variabel bebas terhadap variabel tidak bebas.

1. Uji t (uji persial)

Pengujian secara persial adalah untuk mengetahui apakah secara parsial setiap variabel bebas mempunyai pengaruh atau tidak terhadap variabel tidak bebas. Ho : $\mathrm{b} 1=\mathrm{b} 2=0$, artinya tidak terdapat pengaruh yang nyata baik b1 maupun b2.

Pembuktian ini dilakukan dengan mengamati $\mathrm{t}$ ( $\mathrm{t}$ hitung) pada nilai $\mathrm{a}=5 \%$ Apabila nilai $\mathrm{t}$ lebih besar atau sama dengan 1 tabel maka Ho ditolak dan Ho ditolak dan Ha diterima.

2. Uji F (Uji Serentak)

Pengujian serentak digunakan untuk menguji apakah secara serentak setiap variabel bebas mempunyai pengaruh atau tidak terhadap variabel tidak bebas.

Ho : $\mathrm{b} 1=0$, artinya tidak terdapat pengaruh yang nyata $b 1$ terhadap produktivitas.

Ho : b1 \# 0, artinya terdapat pengaruh yang nyata b1 terhadap produktivitas.
Pembuktian ini dilakukan dengan mengamati Fo (F hitung) pada nilai $\mathrm{a}=5 \%$.

Apabila nilai Fo lebih besar dari pada $\mathrm{F}$ tabel maka Ho ditolak dan Ha diterima.

3. Perhitungan Koefisien Determinasi $\left(\mathrm{R}^{2}\right)$

Koefisien ditermidasi digunakan untuk mengetahui kuatnya pengaruh antara variabel tidak bebas dengan variabel bebas. Jika $<0,50$ maka hubungan $\mathrm{X}$ dan Y lemah (+) atau (-) Jika $0,50-0,75$ maka hubungan $\mathrm{X}$ dan $\mathrm{Y}$ sedang $(+)$ atau (-) Jika 0,75 - 0,90 maka hubungan $\mathrm{X}$ dan $\mathrm{Y}$ mendeklati sempurna $(+)$ atau (-)

Jika $=1$ maka hubungan $\mathrm{X}$ dan Y sempurna (+) atau (-) Jika $=0$ maka antara $\mathrm{X}$ dan $\mathrm{Y}$ tidak berhubungan sama sekali.

4. Perhitungan Koefisien

Determinasi Parsial $\left(\mathrm{r}^{2}\right)$

Perhitungan determinasi parsial digunakan untuk mengukur besarnya pengaruh antara dua variabel atau lebih. Semakin besar nilai $\mathrm{r}^{2}$ maka akan semakin kuat pengaruh antara variabel bebas dengan tidak bebas. 
Untuk memudahkan responden menjawab dalam berbagai tindakan dalam kuisioner maka digunakan format tipe Likert, pada ujung sebelah kiri (dengan angka besar) menggambarkan suatu jawaban yang positif sedangkan pada ujung sebelah kanan (dengan angka kecil) menggambarkan suatu jawaban yang negatif.

Alat analisis dan semua alat pengujian hipotesis ini menggunakan perhitungan program komputer SPSS.

\section{ANALISIS DAN PEMBAHASAN}

\section{Analisis}

PT. Columbus Megah

Sentrasarana berawal dari sebuah toko elektronik dengan nama "Toko Columbus" yang terletak di jalan Letkol Iskandar No 31 D Palembang. Penjualan barang elektronik toko Columbus semakin hari menunjukkan perkembangan yang cukup berarti, sehingga toko Columbus menjadi salah satu toko elektronik yang cukup besar di kota Palembang.

Seiring dengan berjalannya waktu, persaingan di bidang penjualan elektronik semakin meningkat, sehingga terjadi suatu persaingan yang cukup kompetitif.
Dalam situasi seperti ini para pendiri melihat bahwa di masa depan permintaan masyarakat akan barang-barang elektronik akan terus meningkat, tetapi di sisi lain daya beli masyarakat masih rendah. Kenyataan ini justru dilihat sebagai potensi pasar terbesar yang harus segera digarap dan diolah. Beranjak dari latar belakang pemikiran inilah akhirnya pada tahun 2001, didirikan PT. Colombus Megah Sentrasarana yang dipelopori oleh Z. Haris Nasution, Basuki Lindin dan Darma Sihombing.

PT. Colombus Megah Sentrasarana merubah strategi pemasarannya dengan melancarkan penjualan dengan sistem penjualan tunai dan kredit untuk meraih pangsa pasar golongan menegah ke bawah. Melimpahnya order permohonan kredit mendorong perusahaan untuk lebih meningkatkan mutu kerja. Sedikit demi sedikit manajemen, administrasi dan stertegi perusahaan mulai dibenahi, terutama di bidang administrasi. Tenaga-tenaga operasional di didik dan di latih 
baik keterampilan, pengetahuan, moral maupun mental. Keahlian kerja ditingkatkan menuju efektivitas dan efisiensi upaya ini tidak percuma terbukti dari adanya peningkatan omzet dari waktu ke waktu. Menyadari bidang bisnis ini sebagai lahan yang memberikan harapan yang demikian cerah, maka bermunculan pula perusahaan sejenis sebagai kompetitor. Hal ini sepenuhnya disadari oleh pihak manajemen untuk berjuang dan mempertahan eksistensinya dengan pengembangan nilai-nilai bisnis baik budaya korporate yang baik maupun sistem pelayanan yang memuaskan.

Salah satu cabang dari PT. Columbus Megah Sentrasarana didirikan di Samarinda pada tanggal 27 Juli 2005 yang merupakan salah satu cabang yang mengkoordinir pemasaran produk untuk wilayah kota Samarinda. Perusahaan beralamat di Jalan Dr. Sutomo No 67 yang dipimpin oleh Bapak Mahyudi.

Seperti juga halnya
perusahaan lainnya, perjalanan usaha PT. Colombus Megah Sentrasarana di Samarinda tidak lepas dari tantangan persaingan. Namun karena kegigihan serta strategi yang mantap, perusahaan memperoleh pangsa pasar yang cukup berarti di kota Samarinda.

\section{Pembahasan}

Untuk memperoleh jawaban atas permasalahan yang dihadapi, maka data-data hasil kuisioner perlu dianalisis dengan menggunakan melalui perhitungan tersebut yaitu analisis regresi berganda dengan menggunakan SPSS versi 17 dengan hasil sebagai berikut:

Berdasarkan hasil analisis menggunakan program SPSS Ver. 17 terhadap data penelitian yang telah didapat dan telah diolah, dan setelah disusun kembali diperoleh persamaan regresi linear berganda sebagai berikut :

$$
\mathrm{Y}=0,038+0,448 \mathrm{X}_{1}+0,605 \mathrm{X}_{2}
$$

Dengan notasi: $\mathrm{Y}$ adalah Produktivitas kerja karyawan pada PT. Colombus Megah Sentrasarana Samarinda.

$\mathrm{X}_{1}$ adalah Motivasi

$\mathrm{X}_{2}$ adalah Semangat Kerja

Persamaan regresi liniear berganda yang telah didapat tersebut 
dapat dijelaskan secara sederhana sebagai berikut:

Jika $X_{1}$ berubah satu satuan, maka Y berubah sebesar 0,448 satuan dengan asumsi $\mathrm{X}_{2}$ konstan.

Jika $\mathrm{X}_{2}$ berubah satu satuan, maka Y berubah sebesar 0,605 satuan dengan asumsi $\mathrm{X}_{1}$ konstan.

Dari lampiran tersebut, diketahui pula bahwa koefisien determinasi $\left(\mathrm{R}^{2}\right)$ diperoleh sebesar 0,769 . Hal ini berarti bahwa kontribusi variabel motivasi $\left(\mathrm{X}_{1}\right)$, dan semangat kerja $\left(\mathrm{X}_{2}\right)$, mempengaruhi produktivitas kerja karyawan pada PT. PT. Colombus Megah Sentrasarana di Samarinda adalah $76,90 \%$, sisanya $23,10 \%$ dipengaruhi oleh variabel lain yang tidak termasuk bagian dari variabel terpilih dalam penelitian ini.

Jika besaran koefisien determinasi $\mathrm{R}^{2}$ tersebut diakarkan, maka diperoleh koefisien korelasi (R) sebesar 0,877 atau $87,70 \%$. Hal ini berarti bahwa secara bersama-sama variabel motivasi $\left(\mathrm{X}_{1}\right)$ dan semangat kerja $\left(\mathrm{X}_{2}\right)$ mempunyai hubungan yang erat dengan produktivitas kerja karyawan pada PT. Colombus Megah Sentrasarana Samarinda.

Dari hasil analisis data seperti terlampir, secara parsial keeratan hubungan antara variabel independen terhadap produktivitas kerja karyawan, secara sederhana dapat dijelaskan sebagai berikut :

Hubungan antara motivasi $\left(\mathrm{X}_{1}\right)$ dengan produktivitas kerja karyawan (Y) sebesar 0,726 atau $72,60 \%$ dengan asumsi $\mathrm{X}_{2}$ konstan.

Hubungan antara semangat kerja $\left(\begin{array}{l}X_{2}\end{array}\right)$ dengan produktivitas kerja karyawan $(\mathrm{Y})$ sebesar 0,781 atau $78,10 \%$ dengan asumsi $\mathrm{X}_{1}$ konstan.

\section{Pengujian Hipotesis}

Pengujian hipotesis dilakukan dengan uji $\mathrm{F}$ dan uji t berdasarkan tabel Analisis of Variance (ANOVA). Pengujian ini sangat penting dilakukan sebagai landasan menerima atau menolak hipotesis yang telah disusun pada Bab sebelumnya.

\section{Hipotesis 1}

Pengujian hipotesis 1 dilakukan dengan uji $\mathrm{F}$ pada tingkat kepercayaan $95 \%$ dan $\alpha 0,05$ diperoleh besaran $\mathrm{F}$ hitung sebesar 69,808 dengan probabilitas Sig. 0,000, sedangkan F tabel sebesar 2,830 dengan $\alpha 0,05$. Hal ini mengindikasikan bahwa variabel motivasi dan semangat kerja secara bersama-sama atau secara stimultan "overall" berpengaruh signifikan terhadap produktivitas kerja karyawan pada PT. Colombus Megah Sentrasarana 
di Samarinda. Dengan demikian hipotesis 1 dapat diterima karena telah teruji kebenarannya.

\section{Hipotesis 2}

Pengujian hipotesis 2 secra parsial dilakukan dengan uji $t$ pada tingkat kepercayaan $95 \%$ dan $\alpha 0,05$. Variabel motivasi t hitung 5,373 $>\mathrm{t}$ tabel 2,021 atau Sig. 0,005<0,05. Berarti ada pengaruh yang signifikan secara parsial antara motivasi terhadap produktivitas kerja karyawan.

Variabel semangat kerja t hitung 6,622 > tabel 2,021 atau Sig. 0,000 < 0,05. Berarti ada pengaruh yang signifikan secara parsial antara semangat kerja terhadap produktivitas kerja karyawan.

Uji $t$ atau uji secara parsial tersebut menggambarkan pengaruh yang signifikan antara faktor motivasi dan semangat kerja terhadap produktivitas kerja karyawan pada PT. PT. Colombus Megah Sentrasarana di Samarinda.

Berdasarkan uji parsial tersebut dan besaran koefisien regresi yang tersaji pada persamaan regresi linier berganda yang dapat diketahui bahwa variabel yang dominan berpengaruh terhadap produktivitas kerja karyawan pada $\mathrm{PT}$. Colombus Megah Sentrasarana di Samarinda adalah variabel semangat kerja karena memiliki koefisien regresi terbesar dibanding koefisien regrasi variabel motivasi. Dengan demikian hipotesis 2 ditolak karena tidak terbukti kebenarannya.

Dengan memperhatikan hasil analisis dengan menggunakan SPSS versi 17 diperoleh persamaan regresi linier berganda sebafai berikut $\mathrm{Y}=$ $0,038+0,448 \mathrm{X}_{1}+0,605 \mathrm{X}_{2}$, yang berarti bahwa variabel motivasi dan semangat secara bersama-sama mempunyai hubungan dengan produktivitas kerja karyawan pada PT. Colombus Megah Sentrasarana di Samarinda.

Koefisien korelasi ( R) sebesar 0,8770 yang berarti bahwa variabel motivasi dan semangat kerja secara bersama-sama mempunyai hubungan searah atau positif dengan produktivitas kerja karyawan pada PT. Colombus Megah Sentrasarana di Samarinda.

Nilai R Squared $\left(\mathrm{R}^{2}\right)$ sebesar 0,769 atau $76,90 \%$ yang berarti produktivitas kerja karyawan pada PT. Colombus Megah Sentrasarana di Samarinda dapat ditentukan oleh variabel motivasi dan semangat kerja. Dengan kata lain bahwa kontribusi motivasi dan semangat kerja terhadap 
produktivitas kerja karyawan pada $\mathrm{PT}$. Colombus Megah Sentrasarana di Samarinda sebesar 76,90\%. Sedangkan sisanya $23,20 \%$ lainnya ditentukan oleh variabel lain diluar penelitian ini.

Sedangkan pengaruh masingmasing variabel yaitu variabel motivasi $\left(\mathrm{X}_{1}\right) \quad$ berpengaruh terhadap produktivitas kerja karyawan sebesar $63,80 \%$, sementara variabel semangat kerja $\left(\mathrm{X}_{2}\right)$ berpengaruh terhadap produktivitas kerja karyawan sebesar $71,50 \%$. Sehingga dapat dikatakan bahwa semangat kerja merupakan variabel yang dominan pengaruhnya terhadap produktivitas kerja karyawan pada PT. Colombus Megah Sentrasarana di Samarinda.

Hal ini dikarenakan semakin besar tingkat pemberian semangat kerja, maka semakin besar pula tingkat produktivitas kerja karyawan yang dihasilkan oleh karyawan pada PT. Colombus Megah Sentrasarana di Samarinda.

Uji hipotesis baik yang pertama dapat diterima karena $\mathrm{F}$ hitung sebesar 69,808 dan $F$ tabel 2,830 yang berarti $F$ hitung $>\mathrm{F}$ tabel . Demikian juga dengan hipotesis kedua dapat diterima karena terbukti bahwa semangat kerja pengaruhnya dominan terhadap produktivitas kerja karyawan pada $\mathrm{PT}$.

Colombus Megah Sentrasarana di Samarinda.

\section{KESIMPULAN DAN SARAN}

\section{Kesimpulan}

Berdasarkan hasil analisis yang telah diuji, baik secara kualitatif maupun kuantitatif dapat disusun beberapa simpulan sebagai berikut:

1. Hipotesis 1 yang menyatakan motivasi dan semangat kerja secara bersama-sama berpengaruh signifikan terhadap produktivitas kerja karyawan pada PT. Colombus Megah Sentrasarana di Samarinda dapat diterima karena telah terbukti kebenarannya. Hal ini berarti bahwa jika faktor-faktor tersebut mengalami peningkatan atau penurunan produktivitas kerja karyawan secara keseluruhan.

2. Hipotesis 2 menyatakan semangat kerja berpengaruh dominan terhadap produktivitas kerja karyawan pada PT. Colombus Megah Sentrasarana Samarinda diterima karena terbukti kebenarannya. Dari hasil analisis dan 
pengujian hipotesis semangat kerja yang berpengaruh dominan terhadap produktivitas kerja karyawan pada PT. Colombus Megah Sentrasarana Samarinda.

3. Kontribusi motivasi dan semangat kerja secara bersama-sama terhadap produktivitas kerja karyawan pada PT. Colombus Megah Sentrasarana di Samarinda adalah sebesar 0,769 atau $76,90 \%$, dan sisanya 0,2390 atau $23,10 \%$ ditentukan oleh faktor lain di luar penelitian ini.

4. Korelasi atau keeratan hubungan antara faktor terpilih (motivasi dan semangat kerja ) dengan produktivitas kerja karyawan pada PT. Colombus Megah Sentrasarana di Samarinda adalah sangat erat dan sempurna karena koefisien korelasi (R) mendekati nilai 1.

\section{Saran}

Berdasarkan hasil analisis dan beberapa simpulan tersebut, dapat disusun beberapa saran sebagai berikut:

1. Diharapkan pimpinan PT. Colombus Megah Sentrasarana
Samarinda dan tetap memberikan perhatian yang optimal terhadap faktor motivasi dan semangat kerja karena semua faktor yang disebut ini sangat berpengaruh terhadap produktivitas kerja karyawan pada PT. Colombus Megah Sentrasarana di Samarinda.

2. Meskipun faktor semangat kerja berpengaruh dominan terhadap produktivitas kerja karyawan pada PT. Colombus Megah Sentrasarana di Jalan Dr. Soetomo Samarinda, namun kiranya faktor-faktor lain yang mempunyai pengaruh terkecil diupayakan ditingkatkan seiring dengan kedudukan, tugas pokok, dan fungsi perusahaan. Hal ini penting dilakukan agar dapat mendorong meningkatkan produkyivitas karyawan menjadi lebih baik.

3. Bagi peneliti berikutnya, terutama yang ingin melakukan penelitian lanjutan sejenis secara komprehensif, kiranya dapat menambah variabelvariabel lain yang relevan ke 
arah pengembangan teori prestasi kerja dan kebijakan pengembangan karyawan khususnya, dan sumber daya manusia pada umumnya.

\section{DAFTAR PUSTAKA}

Abi, Sujak. 2000. Kepemimpinan Manager (Eksistensinya Dalam Perilaku Organisasi), Cetakan Pertama. CV. Rajawali: Jakarta.

Faustino, Gardosa Gomes. 2003. Manajemen Sumber Daya Manusia, Edisi Pertama, Cetakan Ketiga. Andi Offset: Jakarta.

H. Hadari Nawawi. 2003. Perencanaan SDM (Untuk Organisasi Profit yang Kompetitif), Cetakan Pertama. Gadjah Mada University Press: Yogyakarta.

H. Malayu S.P. Hasibuan. 2005. Manajemen Sumber Daya Manusia, Dasar Kunci dan Keberhasilan. Haji Masagung: Jakarta.

Heidjrahman Ranupandojo dan Suad Husnan. 2006. Manajemen Personalia. Andi Offset: Yogyakarta.

Hendry, Simamora. 2004. Manajeme Sumber Daya Manusia, Edisi Ketiga, Cetakan Pertama. STIEYKPN: Yogyakarta.

Husein, Umar. 2004. Riset Akuntansi, Cetakan Kedua. PT. Gramedia Pustaka Utama: Jakarta.
J. Supranto. 2004. Statistik (Teori dan Aplikasi) Jilid I, Edisi Kelima, Cetakan Kedelapan. Erlangga: Jakarta.

Kamaruddin. 2004. Ensiklopedi Manajemen. Alumni: Bandung.

M. Agus Tulus. 2004. Manajemen Sumber Daya Manusia, Cetakan Keempat. PT. Gremedia Pustaka Utama: Jakarta.

Manulang dan Andreas Ginting Munthe. 2003. Manajemen Partisipatif. Pusat Produktivitas Nasional: Jakarta.

Mauled, Mulyono. 2002. Penerapan Produktivitas Dalam Organisasi. Bumi Aksara: Jakarta.

Moekijat. 2002. Manajemen Kepegawaian dan Hubungan Dalam Perusahaan. Alumni: Bandung.

Muchdarsyah, Sinungan. 2002. Produktivitas Apa dan Bagaimana, Edisi Kedua, Cetakan Kedua. PT. Bumi Aksara: Jakarta.

Paul, Hersey dan Ken Blanchard. 2006. Manajemen Perilaku Organisasi Pendayagunaan Sumber Daya Manusia, Ahli Bahasa oleh Agus Dharma, Edisi Keempat. Airlangga: Jakarta.

Rusli, Syarif. 2002. Produktivitas. Angkasa: Bandung.

Scott, Willim G.2002. Human Relation in Management, a Behavioral Ssience Approach 
Riichard D. Irwan Inc, Homewood: Illinois.
T. Hani Handoko. 2005. Manajemen Personalia dan Sumber Daya Manusia, Edisi Kedua, Cetakan Kesebelas. BPFE: Yogyakarta.

Sondang, P. Siagian. 2006. Manajemen Sumber Daya Manusia, Cetakan Keempat. Bumi Aksara: Jakarta. 